\title{
LANGUAGE AND COMMUNITY RESPONSE ON THE APPEAL AND ANNOUNCEMENT OF COVID-19 FOUND IN WEST SUMATERA
}

\author{
Sonezza Ladyanna ${ }^{1)}$, Rona Almos ${ }^{2)}$, Yola Merina ${ }^{3)}$ \\ ${ }^{1,2)}$ Faculty of Humanity, Universitas Andalas, Indonesia \\ ${ }^{3}$ STKIP PGRI Sumatera Barat, Indonesia \\ email: ${ }^{1)}$ sonezzaladyanna@hum.unand.ac.id, ${ }^{2)}$ ronaalmos@hum.unand.ac.id \\ ${ }^{3)}$ yolam3@gmail.com
}

Submitted: $25-10-2020$

Accepted: 29-11-2020

DOI: https://doi.org/10.22202/tus.2020.v6i1.4423

\begin{abstract}
Language in appeals and announcements regarding COVID-19 in public spaces is an important factor in communication regarding the handling of this pandemic. In this regard, this article describes the language and reactions of the public to the appeals and announcements regarding COVID-19. The data source in this study is the language of appeals and announcements regarding COVID-19 in public spaces in West Sumatra Province, Indonesia. The data in this study are linguistic variations and people's responses to linguistic variations in the COVID-19 appeal and announcement. Data collection was carried out through observation and questionnaires. The analysis was carried out in the framework of sociolinguistics. Based on the results of the analysis, it can be concluded that the languages which are used in formal dan informal varieties are Indonesian, English, and Minangkabau language. Interestingly, abbreviations, acronyms, and mixing code were used as well. People have different reactions regarding the use of the language, some agree and disagree, on the other hand there are those who are affected and not. This difference is influenced by age and education. The novelty in this research is the finding that appeals and announcements relating to handling COVID-19 will be more optimal if they are equipped with the number of victims of this virus.
\end{abstract}

Keywords: announcement, appeal, COVID-19, language

\section{INTRODUCTION}

The COVID-19 pandemic is a major problem that occurs in the world and has resulted in major changes in various lines of life. The spread of this virus is moving very massively and has a negative impact on the economy, education and other aspects of life for the world community. COVID-19 has affected communities, businesses and organisations globally, inadvertently affecting the financial markets and the global economy [1]. Various attempts were made to 
contain the number of this virus transmission, including massive campaigns in various media. The government (even the community) has made appeals and announcements regarding the handling of this pandemic so that these appeals and announcements can easily be seen anywhere.

However, the number of people exposed continues to increase (particularly in West Sumatra Province, Indonesia) despite appeals and announcements being posted to remote areas. West Sumatra Province is one of the areas affected by the COVID-19 pandemic with a high positive number [2] As of October 2020, there were more than 3000 people who tested positive for COVID-19[3]. It seems that the appeals and announcements from the government as well as the public and other related parties have not been fully responded to by the community.

Appeals and announcements commonly found in public places are conveyed in language and pictures. Language can be used to change people's thoughts or ideologies and also to control people's thoughts[4]. Other reasearch results that the structural equation model shows that there an impact of the language of COVID19 on the discourse of fear and Sinophobia [5]. However, the growing number of victims of the COVID-19 virus shows an indication that these calls and announcements have not yet reached their targets.

Ladyanna and Rona Almos have conducted research on the use of language in appeals and announcements regarding the handling of the COVID-19 pandemic, but only a description of trending terms during this pandemic [6]. Meanwhile, the use of language and the community's response to these appeals and announcements must be presented immediately so that an appropriate model for appeals and announcements can be found. Therefore, research on the use of language and the public's response to the use of language in appeals and announcements regarding handling COVID-19 is important.

In this regard, this article explains 1) the use of language in appeals and announcements regarding the handling of the COVID-19 pandemic and 2) the public's response to the use of language in appeals and announcements related to handling the COVID-19 pandemic. This research is analyzed in the realm of 
sociolinguistic studies. Thus, it will explain the variations in the language used and the public response to the use of that language.

Sociolinguistics is the science used to study the relationship between language behavior and social behavior [7]. From the thought that language is a social phenomenon, language and its usage are determined by linguistic and nonlinguistic factors such as social and situational factors [8]. Social factors are social factors that influence language use, for example social status, economic level, and education level. Furthermore, it is explained that the situational factors include; who is speaking, in what language, to whom, when, where, and on what matters. In short, sociolinguistics became the theory which is used to society analysis.

\section{METHODS}

This research is a sociolinguistic research. This research was conducted in West Sumatra Province, Indonesia, both in person and online. The data in this study are variations in the form of language contained in appeals and announcements about COVID-19. Then, the community's response to the language used in these appeals and announcements.

Data collection has been carried out since May 2020. Data on variations in language forms in appeals and announcements is collected through observation of bulletin boards located on the sides of main roads, houses of worship, schools, health care centers, markets, and other crowded places in Sumatra Province. West, Indonesia. After that, the data will be grouped according to their variations.

After the data on the variety of language forms were obtained, a survey was conducted on the public response to the language. Data regarding community responses is collected through questionnaires distributed online and also through interviews with people who are assumed not to fill out online questionnaires. The people in question are people who were in the research area when the research was conducted and were not used to filling out online questionnaires. Respondents are people who can read from the age of 15 to 52 years with undergraduate education as much as $78.1 \%$, high school $20.1 \%$, and postgraduate 2 as much as $1.9 \%$. Then, the data were analyzed using sociolinguistic studies. 


\section{FINDING AND DISCUSSION}

Based on the research conducted, it was found that the language used in appeals and announcements related to COVID-19 was Indonesian with formal and informal forms, English and Minangkabau languages. Then, the use of abbreviations, acronyms, and code mixing were also found. The community gives different responses to the form of the language used. This response is in the form of agreement and influence which is influenced by the age and education of the respondent.

Generally, the language used in appeals and announcements related to COVID-19 is formal Indonesian. The official or formal variety is a variety of languages that already have established patterns and rules as a standard and are used in official situations. [9]. Indonesian is the official language stated in Article 36 of the 1945 Constitution of the Unitary State of the Republic of Indonesia. In Indonesian, there is a formal variety or an official variety and an informal variety. Indonesian is used in accordance with the situation and conditions based on the rules issued by the government of the Republic of Indonesia.

It is also found that the use of Indonesian language is not formal as in the following data.

\begin{tabular}{|l|l|}
\hline Kok masih di sini.... & Why are you still here... \\
\hline Emang penting? & Is this important? \\
\hline Ayo! \#diRumahAja & Come on! \#stayathome \\
\hline Physical distancing & Physical distancing \\
\hline Nyaman bersama pln & Comfortable with PLN \\
\hline
\end{tabular}

Informal forms are used to follow and adapt to communication situations and situations [8]. The communication situation in question is who, to whom, what problems, and goals. Thus, in the informal variety, several forms of linguistic aspects can be found, such as the use of foreign languages and regional languages. So, there is English, namely the term "physical distancing". Several terms that have been popular since the COVID-19 pandemic are often used in English, such as physical distancing, social distancing, new normal, and hand sanitizer. 
The Minangkabau language as the regional language in this region is also used in several appeals and announcements regarding COVID-19.

\begin{tabular}{|c|c|}
\hline antian covid-19 manjala & stop the spread of Covid-19 \\
\hline $\begin{array}{l}\text { \#jagojarak } \\
\text { Jago jarak katiko basobok jo urang dan } \\
\text { jan diawai }\end{array}$ & $\begin{array}{l}\text { \# keepphysicaldistance } \\
\text { keep your distance when meeting people } \\
\text { and don't touch }\end{array}$ \\
\hline $\begin{array}{l}\text { \#basuahtangan } \\
\text { Acok basuah tangan pakai sabun jo aia } \\
\text { mailia }\end{array}$ & $\begin{array}{l}\text { \#washinghands } \\
\text { Wash hands frequently with soap and } \\
\text { running water }\end{array}$ \\
\hline $\begin{array}{l}\text { \#dirumahselah } \\
\text { Kok dak paralu-paralu bana jan malala } \\
\text { kalua }\end{array}$ & $\begin{array}{l}\text { \#stayathome } \\
\text { don't leave the house unnecessarily }\end{array}$ \\
\hline $\begin{array}{l}\text { \#liburindakliburan } \\
\text { Indak kasikolah, kampus atau kantua, } \\
\text { karano bisa manambah risiko manjala }\end{array}$ & $\begin{array}{l}\text { \#holidayisnotvacation } \\
\text { not to schools, colleges, or offices because } \\
\text { they can increase the risk of spreading }\end{array}$ \\
\hline $\begin{array}{l}\text { \#jagomakanan } \\
\text { Pabanyak makanan nan bagizi, } \\
\text { pabanyak makan sayua jo buah }\end{array}$ & $\begin{array}{l}\text { \#takecareofthefood } \\
\text { eat more a nutritious food, eat more fruits } \\
\text { and vegetables }\end{array}$ \\
\hline $\begin{array}{l}\text { \#iduiksehaik } \\
\text { Indak maisok, cukuik lalok olahraga } \\
\text { supayo badan sehaik }\end{array}$ & $\begin{array}{l}\text { \#healthylife } \\
\text { not smoking, getting enough sleep, } \\
\text { exercise, for a healthy body }\end{array}$ \\
\hline $\begin{array}{l}\text { \#janlupobasuahtangan } \\
\text { (Padang cement Indonesia) }\end{array}$ & \# don'tforgettowashyourhands \\
\hline
\end{tabular}

Minangkabau language is used in its entirety without adding the meaning in the national language, namely Indonesian.

In appeals and announcements related to COVID-19, the use of abbreviations and acronyms was also found. Abbreviation is the result of the shortening process in the form of letters or a combination of letters [7]. Acronym is an abbreviation in the form of a combination of letters or syllables or other parts that are written and pronounced as a word in accordance with the phonotactic rules of the language concerned [7], so that the new symbols are easy to pronounce and look attractive. The abbreviations found are the same as the research results of Ladyanna and Rona Almos (2020) that ODP (Orang Dalam Pantauan), OTG (Orang Tanpa Gejala), PDP (Pasien Dalam Pantauan), APD (Alat Pelindung Diri), PSBB (Pembatasan Sosial Berskala Besar), and HS (Hand Sanitizer).

The new interesting finding in this study are in the form of an acronym namely "AEROBIC" which is an acronym of "Aksi Gotong Royong Bersih 
COVID-19". Aerobic is an English word that means relating to or denoting exercise that improves or is intended to improve the efficiency of the body's cardiovascular system in absorbing and transporting oxygen [10]. However, in this study, "aerobic" is used as an acronym for "Aksi Gotong Royong Bersih COVID-19" which is an activity to clean up an area in mutual cooperation to prevent the spread of COVID-19 in the area.

Another form of language that was found was code mixing. Generally, code mixing occurs between Indonesian and English. According to Chaer and Leony [11], code mixing and interference are closely related. Code mixing is the use of bits and pieces from another language, which can be in the form of words or phrases, in a language that may be necessary, so that it is not considered an error or deviation. English codes are used in Indonesian speech. All terms popular in this pandemic are retained in English even though the speech is in Indonesian as shown in the following data.

\begin{tabular}{l}
\hline Tatanan kehidupan baru (New Normal masjid \\
Raya Gantiang)... \\
\hline Jaga jarak/ physical distancing... \\
\hline
\end{tabular}

In addition, code mixing is also used to emphasize several terms so that there is no doubt that multilingual visitors to the place, as in the following data.

\begin{tabular}{|l|l|}
\hline $\begin{array}{l}\text { Kami rutin membersihkan area tempat } \\
\text { makan/ sitting area dengan disinfektan }\end{array}$ & $\begin{array}{l}\text { We regularly clean the sitting area with } \\
\text { disinfectant }\end{array}$ \\
\hline $\begin{array}{l}\text { Mulai tanggal 08 Juni 2020 kami } \\
\text { kembali melayani Dine In }\end{array}$ & $\begin{array}{l}\text { Starting on June 8, 2020 we are back to } \\
\text { serving Dine In }\end{array}$ \\
\hline
\end{tabular}

Notifications and announcements can easily be seen in public places in the form of information boards, banners or murals. Only $9 \%$ of respondents stated that these appeals and announcements were difficult to see. The government has been making appeals and announcements since the pandemic started in a place that has been visited by many people. In fact, the local community has also made appeals and announcements that can usually be seen at places of worship and housing entrances. 
The community gives different responses to the form of the language used. The use of Indonesian in appeals and announcements related to the COVID-19 pandemic received a positive response from respondents in the study. Only $1.1 \%$ disagreed with this opinion. In contrast to the results of other studies in Europe which state that the use of English is easier to understand in advertisements than the use of local languages [12]. Thus, Indonesian as the official language of the Unitary State of the Republic of Indonesia is clearly an effective means of communication for all Indonesian citizens.

The informal variety is preferred by respondents aged 15 to 25 because it is considered easier to understand. Informal variations on appeals and announcements regarding the COVID-19 pandemic are considered close to their daily language. In fact, regional languages in other appeals also received good responses from respondents aged 15 to 25 with a response rate of $72.4 \%$ [13]. For the use of regional languages, $26.4 \%$ of respondents stated that the use of regional languages is easier to understand. These findings were obtained from respondents with high school education and living in rural areas with jobs as farmers and small traders. Appropriately, the makers of the appeal and information also pay attention to the location of the information and the appeal is conveyed. The use of regional languages is better understood by rural communities.

Furthermore, only $43.3 \%$ of respondents stated that the use of abbreviations can be understood easily. Meanwhile, some terms in the form of abbreviations are often used by the government and sometimes are not accompanied by an abbreviation. These abbreviations confuse the public and thus ignore the contents of the appeal and announcement. In fact, these appeals and announcements contain information that is needed by the community.

Meanwhile, $58.8 \%$ of respondents stated that the use of foreign terms is easy to understand. The percentage of respondents understanding is higher about the use of foreign terms than abbreviations. The foreign term referred to is the use of English, namely in the terms "social distancing", "physical distancing", "lockdown", and "hand sanitizer". After the outbreak of the COVID-19 pandemic, these terms became trending and were used repeatedly through news, health 
campaigns, advertisements, social media, and eventually became general terms for the entire community.

Unlike the case with abbreviations that appear in quite a number of numbers with insignificant differences, both in terms of form and meaning, such as in ODP, PDP, and OTG. Many respondents were confused by these terms. The new term for society requires socialization so that all levels of society can understand it. Moreover, the new term was shortened. Then, the abbreviation is used without including the complete elements, it will cause confusion for the community and finally the community will ignore the appeal and announcement..

For the term PSBB, most respondents understood the meaning but did not know the exact length of the term. Respondents' high level of understanding was due to the meaning that PSBB had a significant impact on people's lives. PSBB or Large-Scale Social Restrictions, which is a government policy that prohibits the gathering of large numbers of people [14]. Similar to the lockdown, in the PSBB, the movement of people from one city to another, restricting economic activities, worship, and limited education. Policies that have many impacts are easier for the public to remember and understand, even though they are only written in an abbreviated form. Respondents better understand the meaning of this abbreviation but do not know what it stands for.

As many as $59.1 \%$ of respondents stated that information about the number of people exposed to the COVID-19 pandemic and the effects of this virus could affect them. These findings indicate that appeals and announcements regarding the handling of the COVID-19 pandemic need to consider information on the number of victims. With the information regarding victims of this virus, the public will immediately heed the appeal.

Based on these findings, there are several things that must be considered in the use of language in appeals and information related to handling the COVID-19 pandemic. First, the variety of language used must be adjusted to the objectives of these appeals and announcements. The use of formal styles is a common choice. Meanwhile, the use of informal modes must be adapted to the objectives of these 
appeals and announcements. Some young people will be closer to appeals that use their everyday language.

In addition, the local culture in speaking must also be considered when choosing a speech style. Minangkabau culture teaches "tiok kato baalamaik" which means someone must use address term to start a conversation or to respect other people because it is going to be good manners in the Minangkabau culture [15]. Using the address term, especially the special address form, will be more effective. Minangkabauneese is very proud of family relationship and feel nearer than before if we can call them by using special address form [16].

The use of language must also be adapted to the place of appeal and the announcement is placed with attention to visitors to that place. For example, the use of regional languages in traditional markets or houses of worship in rural areas which are not crossroads with low community mobilization should use languages that are familiar to them such as local languages besides Indonesian.

Then, the use of the abbreviation must be followed by the abbreviation of the abbreviation so as not to cause confusion from the reader. Foreign terms are not a problem when used. However, the term must be a term that is familiar to the public. The use of mixed codes is one variation in making appeals and announcements regarding the handling of COVID-19, especially mixing Indonesian language codes with regional languages so that the message to be conveyed arrives faster due to the proximity of the community to the terms used.

Furthermore, the content of appeals and announcements also deserves consideration. Community negligence in following the COVID-19 protocol was not the result of insufficient appeals and announcements. Appeals and announcements can be easily accessed by the public. One of the factors that resulted in the negligence was the suboptimal content of the appeals and announcements. Public appeals and announcements have not shown significant information about the victims of this virus and the effects of this virus. Meanwhile, based on this research, it was found that informing the number of temporary victims and the effects of this virus is the right solution so that the public cares about the contents of the appeal and announcement. 
Each type of appeal and announcement target requires a different language strategy even though it is still associated with a disease or virus. Sartika states that The communication strategy of the AIDS Commission in disseminating HIV / AIDS must take a psychological approach and pay attention to the frequency of socialization [17]. In other results, research on calls for the use of safeguards in sexual activity has concluded that an effective strategy is more about precisely the form of media used [18].

Based on Ladyanna and Rona Almos' research, the use of language in public spaces must consider the culture and local wisdom of the people of the region [19]. In addition to considering local culture and wisdom, it must also be considered the intended objectives of these appeals and announcements. Thus, it can be determined what language is used, which language variations are used, how to convey the content, and what media is used.

\section{CONCLUSION}

Based on data exposure and discussion, it can be concluded that appeals and announcements regarding the handling of COVID-19 use formal and informal Indonesian languages, English, Minangkabau language, abbreviations, acronyms, and mixed codes. Based on the public response to the use of the language, language determination; delivery method; contents; and the media used in conveying appeals and announcements must be tailored to the intended targets. The new finding in the appeal and announcement regarding COVID-19 is that information about the number of victims can increase public attention to the appeal and announcement made. In short, people need to pay attention carefully into the content of the advertisement as well as to be aware of the message which is blown up on it.

\section{ACKNOWLEDGMENTS}

Thank you to the Universitas Andalas who has supported this research with the contract Penelitian Riset Dasar (RD) Nomor: T/30/UN.16.17/PT.01.03/SoshumRD/2020, Tahun Anggaran 2020. Thank you also to the LPPM, Jurusan Sastra Indonesia and Jurusan Sastra Minang, Fakultas Ilmu Budaya, Universitas 
Andalas, which has provided assistance and facilities in this research related to the study of sosiolinguistics.

\section{REFERENCES}

[1] M. Nicola et al., "The socio-economic implications of the coronavirus pandemic (COVID-19): A review," Elsevier Public Heal. Emerg. Collect., pp. 185-193, 2020, doi: 10.1016/j.ijsu.2020.04.018.

[2] CNN Indonesia, "Covid-19 Dianggap Konspirasi, Kasus Positif Tinggi di Sumbar," CNN Indonesia, 2020. .

[3] "Pembaharuan Terakhir Data Pantauan Covid19," https://corona.sumbarprov.go.id/, 2020. .

[4] L. Thonas and S. Wareing, Bahasa, Masyarakat dan Kekuasaan. Yogyakarta: Pustaka Pelajar, 2007.

[5] M. S. Rafi, "Language of COVID-19: Discourse of Fear and Sinophobia," Soc. Sci. Humanit. Open, 2020.

[6] S. Ladyanna and R. Almos, "Istilah Trending Pandemi Covid-19 dalam KAJIAN SOSIOLINGUISTIK," in Dinamika Bahasa dalam Era 4.0, 2020, p. 645.

[7] H. Kridalaksana, Kamus Linguistik. Jakarta: Pt Gramedia Pusat Utama, 1993.

[8] I. D. P. Wijana and M. Rohmadi, Sosiolinguistik Kajian Teori dan Analisis. Yogyakarta: Pustaka Pelajar, 2006.

[9] Aslinda and L. Syafyahya, Pengantar Sosiolinguistik. Bandung: PT Refika Aditama, 2007.

[10] A. Chaer and L. Agustina, Sosiolinguistik Perkenalan Awal. Jakarta: Rineka Cipta, 2004.

[11] J. Hornikx, F. Van Meurs, and A. De Boer, "English or a Local Language in Advertising?: The Appreciation of Easy and Difficult English Slogans in the Netherlands," Sage Journals, 2010.

[12] H. Adelfina, "Respon Remaja Mengenai Iklan Layanan Masyarakat Dalam Dialek Lokal Pada Radio Swara Alam Kota Kendari (Studi Khalayak Di Kelurahan Kadia)," J. Ilmu Komun. UHO J. Penelit. Kaji. Ilmu Komun. dan Inf., vol. 1, no. 2, 2016.

[13] ROKOM, "PSBB Putuskan Penularan Covid-19," Kementrian Kesehatan Republik Indonesia, 2020. .

[14] M. Denil, "The Forms Of Kinship Term In Minangkabaulanguage Used By Nagari Simawang Society," Tell-Us J. Teaching-English-LinguisticsLiteratur-usage, vol. 5, no. 1, 2019.

[15] H. Sevrika, "Address Forms in Minangkabau Language at Pariaman Region of West Sumatera in Indonesia," Tell-Us J. Teaching-EnglishLinguistics-Literatur-usage, vol. 2, no. 1, 2016.

[16] A. Sartika, ""Strategi Komunikasi Komisi Penanggulangan AIDS (KPA) dalam melakukan sosialisasi HIV/AIDS di Kota Samarinda.," E-Journal Ilmu Komun., vol. 3, no. 1, pp. 17-30., 2015, [Online]. Available: 
ejournal.ilkom.fisip-unmul.ac.id.

[17] C. Atkin, "Impact of public service advertising: Research evidence and effective strategies," Menlo Park, CA, 2001. [Online]. Available: https://scholar.google.com/scholar?hl=en\&as_sdt=0\%2C5\&q=Atkins\%2C + Charles. $+2001 .+{ }^{\text {"Impact }}+$ of + Public + Service+Advertising + Research + Evi dence+and+Effective+Strategies". $+\& b$ tnG $=$.

[18] S. Ladyanna and R. Almos, "Language in the Provincial Capital Public Space in the Perspective of Local Wisdom," in INCOLWIS 2, 2019. 